\title{
Amaurosis fugax as initial symptom of metastatic clear cell renal carcinoma
}

\author{
Amaurose fugaz como sintoma inicial de carcinoma de células renais metastático
}

\author{
José Renan Miranda Cavalcante Filho ${ }^{1}$, Rafael Paiva Arruda² ${ }^{2}$ Elson Arruda Linhares ${ }^{3}$, \\ Paulo Roberto Lacerda Leal ${ }^{4}$, Irismar de Azevedo Andrade ${ }^{2}$, Karlos Jennysson Sousa Soares ${ }^{3}$
}

Cavalcante-Filho JRM, Arruda RP, Linhares EA, Leal PRL, Andrade IA, Soares KJS. Amaurosis fugax as initial symptom of metastatic clear cell renal carcinoma / Amaurose fugaz como sintoma inicial de carcinoma de células renais metastático. Rev Med (São Paulo). 2019 Sept-Oct;98(5):358-61.

RESUMO: Introdução: Neste caso, descrevemos a apresentação rara da metástase orbitária de um carcinoma renal de células claras. Apresentação do caso: Apresentamos um caso de um homem de 57 anos de idade, que subitamente perdeu a visão em seu olho esquerdo associada à paralisia da abdução do mesmo. A ressonância magnética do crânio revelou um tumor intra-orbitário esquerdo com dimensões de $21,8 \times 19,6 \mathrm{~mm}$, provocando um deslocamento centro-lateral com consequente compressão do nervo óptico e do músculo reto lateral homolateral. O paciente foi submetido à remoção cirúrgica da lesão. O diagnóstico histológico indicou metástase de carcinoma renal de células claras confirmada pela tomografia computadorizada abdominal (TC), que apresentou neoplasia no terço superior do rim esquerdo, medindo $3,5 \times 3,4$ $\mathrm{cm}$ com reforço heterogêneo após administração intravenosa de contraste. Conclusão: Este caso descreveu a apresentação rara de uma metástase orbital de carcinoma renal de células claras. A apresentação inicial do paciente foi amarose fugaz e paralisia homolateral do nervo abducente. A metástase orbital de carcinoma renal de células claras é rara, no entanto, o exame histológico conclui o diagnóstico.

Descritores: Carcinoma de células renais; Neoplasias renais/ diagnóstico por imagem; Amaurose fugaz; Neoplasias orbitárias; Doenças do nervo abducente.

\begin{abstract}
Background: In this case we describe the rare presentation of orbital metastasis of a clear cell renal carcinoma. Case Report: We present a case of a 57-year-old male with suddenly lost the vision in his left eye and homolateral abducens palsy. The magnetic resonance imaging of the skull revealed a left intraorbital tumor with center-lateral displacement measuring $21.8 \times 19.6 \mathrm{~mm}$, compressing the optic nerve and the homolateral lateral rectus muscle. The patient underwent surgical removal of the lesion. The histologic diagnosis indicated clear cell renal carcinoma metastasis confirmed by the abdominal computed tomography $(\mathrm{CT})$, which showed a neoplasia in the upper third of the left kidney measuring $3.5 \times 3.4 \mathrm{~cm}$ with heterogeneous reinforcement after intravenous contrast administration. Conclusion: This case described the rare presentation of a clear cell renal carcinoma metastasis in orbit. The initial presentation of patient was amarosis fugax and homolateral abducens palsy. Orbital metastasis of clear cell renal carcinoma are rare, however, the histologic exam conclude the diagnosis.
\end{abstract}

Keywords: Carcinoma, renal cell; Kidney neoplasms/diagnostic imaging; Orbital neoplasms; Amaurosis fugax; Abducens nerve diseases.

1. Residente de Neurocirurgia do Hospital Regional de Presidente Prudente, SP. ORCID: https://orcid.org/0000-0002-8656-5488. Email: renanmiranda_@hotmail.com.

2. Urologista da Santa Casa de Misericórdia de Sobral, Sobral, CE. ORCID: Arruda RP - https://orcid.org/0000-0001-6440-7350; Andrade I - https://orcid.org/0000-0001-7226-1822.Email: rafa.rpa@gmail.com, irismar_andrade@yahoo.com.br

3. Cirurgião Geral da Santa Casa de Misericórdia de Sobral, Sobral, CE. ORCID: Linhares EA - https://orcid.org/0000-0002-74166391; Soares KJS - https://orcid.org/0000-0003-1704-9137. Email: coelho.linhares@ig.com.br; kajotass@yahoo.com.br.

4. Neurocirurgião da Santa Casa de Misericórdia de Sobral, Sobral, CE. Orcid: https://orcid.org/0000-0002-2489-3777.Email: prlleal@ hotmail.com

Correspondence: José Renan M. Cavalcante Filho. Rua Jorge Gushiken, 405 - Condomínio Vila Paris - Casa 20. Presidente Prudente, SP. 


\section{INTRODUCTION}

Renal cell carcinoma (RCC) accounts for $3 \%$ of frequent in males. Clear cell renal carcinoma (CCRC) is most prevalent variant of this neoplasia, responsible for 70 to $75 \%$ of all cases ${ }^{1}$. As the most frequent metastasis are breast (48\%), prostate $(12 \%)$, skin $(12 \%)$ and lungs $(8 \%)^{2}$. Orbital metastasis are rare and represents less than $2 \%$ of all ophtalmics metastasis. We report the case of a patient with renal cell carcinoma who presented the symptoms of orbital metastasis as the initial manifestation of the disease.

\section{CASE REPORT}

Male, 57 years old, without comorbidities (systemic arterial hypertension, diabetes mellitus), who did not take any medication for chronic conditions, and ex-smoker, attended the Neurosurgery Department at the Santa Casa de Misericórdia de Sobral Hospital. This patient reported that six months ago suddenly lost the vision in his left eye and that it had been deviated medially (Figure 1), with no other associated symptoms.

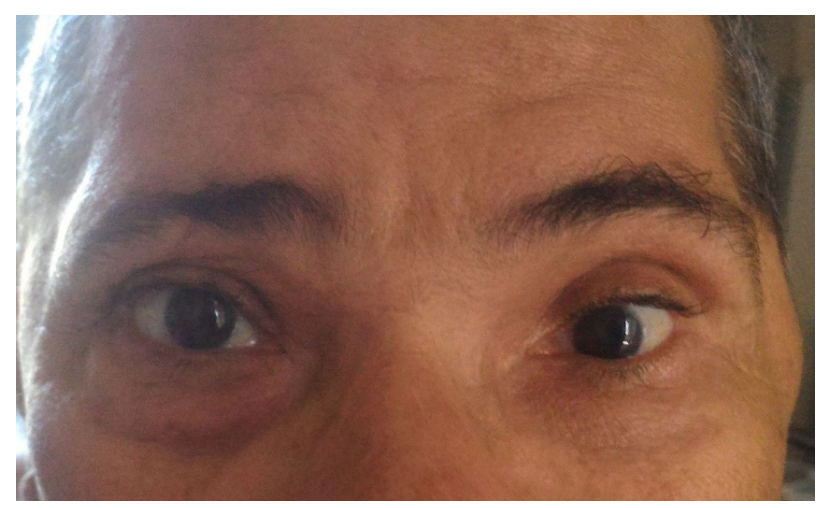

Figure 1. Patient with esotropia of the left eye due to involvement of the ipsilateral lateral rectus muscle

Upon admission, the patient's only complaint was of amaurosis of the left eye. He denied other symptoms: hematuria, dysuria, or back pain. Physical examination showed no visceromegaly or abdominal mass. The magnetic resonance imaging of the skull revealed a left intraorbital tumor with center-lateral displacement measuring $21.8 \times 19.6 \mathrm{~mm}$, compressing the optic nerve and the homolateral lateral rectus muscle (Figure 2). From the results of the exam, surgical removal of the orbital tumor was indicated (12/02/2016). The histopathological report was compatible with CCRCC and confirmed with immunohistochemistry (Table 1)

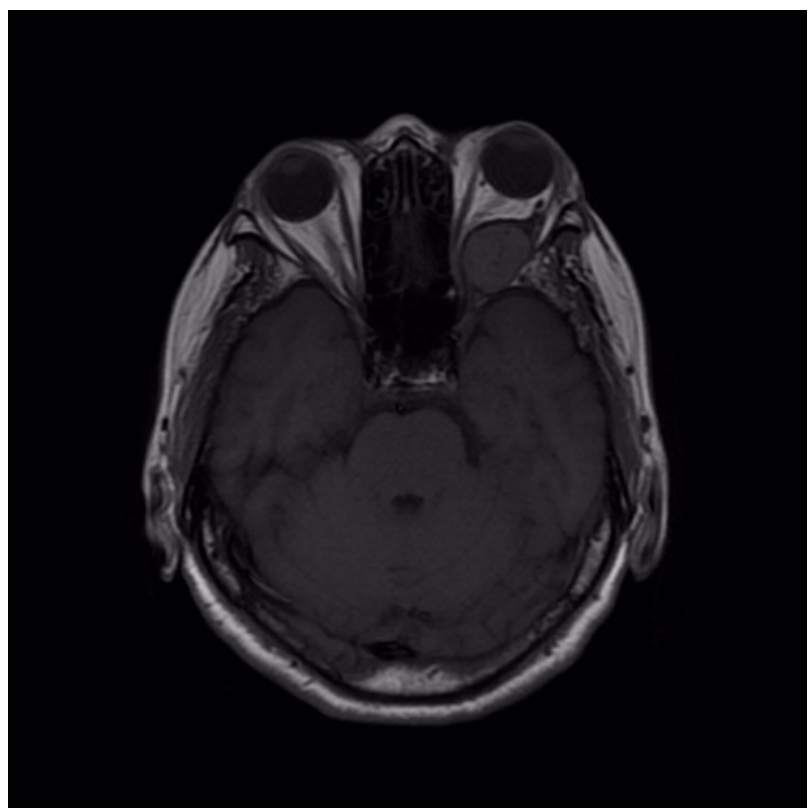

Figure 2. T1-weighted magnetic resonance imaging showing metastatic tumor from renal cell carcinoma in the left orbit. Center-lateral displacement compressing the optic nerve and the lateral rectus muscle. Dimensions: 21.8 x $19.6 \mathrm{~mm}$

Table 1: Left-orbit immunohistochemistry report

\begin{tabular}{l|l|l}
\hline \multicolumn{3}{c}{ Accompanying Files } \\
\hline Antibody & \multicolumn{1}{|l}{ Clone } & \multicolumn{1}{l}{ Interpretation } \\
RCC & PN15 & Positive \\
EMA & E29 & Positive \\
CK7 & OV-TL-12/30 & Negative \\
TTF-1 & 8 G7/1 & Negative \\
VIMENTINA & V9 & Negative \\
CD10 & $56 C 6$ & Negative \\
PAX8 & MRQ-50 & Negative \\
CK20 & K20.8 & Negative \\
\hline
\end{tabular}

The clinical investigation of the patient proceeded with the request of an abdominal computed tomography (CT), which showed (neoplasia in the upper third of the left kidney measuring $3.5 \times 3.4 \mathrm{~cm}$ with 
heterogeneous reinforcement after intravenous contrast administration(white arrow) (Figure 3) and a chest CT (nodular image with homogeneous reinforcement after the use of intravenous contrast in the anterior segment of the upper lobe of the left lung. Suggestive of metastatic nodule, associated with left perihilar lymph node enlargement). According to findings from the complementary exams, partial nephrectomy surgery for tumor resection in the left kidney was indicated (30/08/2016).

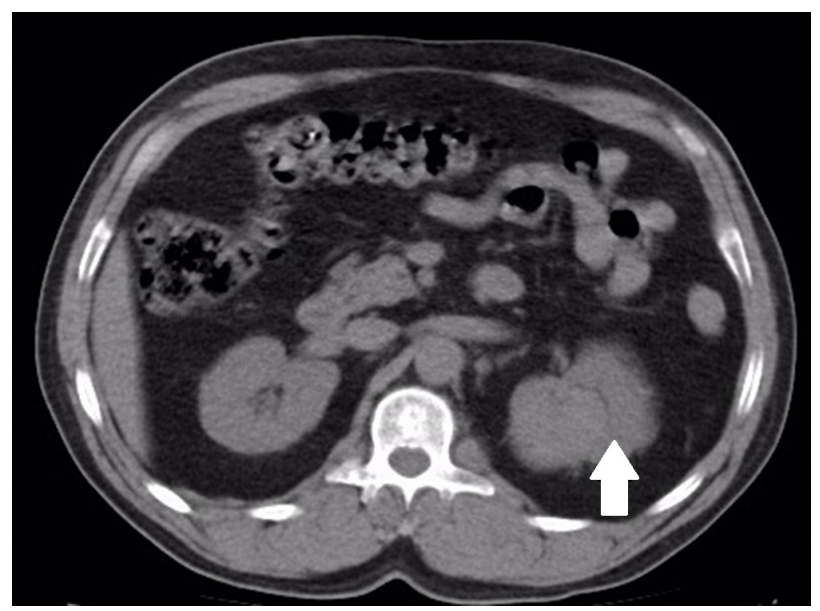

Figure 3. Axial section of computed tomography of abdomen revealed tumor mass in the left kidney measuring $3.5 \times 3.4 \mathrm{~cm}$

\section{DISCUSSION}

Although the case reported belonged to the epidemiological group most commonly affected by RCC (male and in the 5th and 6th decade of life), it is worth highlighting due to its unusual clinical presentation and atypical evolution of ocular symptoms. Classically, the most characteristic symptoms of metastatic orbital RCC are: proptosis, ptosis, and pain, all of which are absent in this report. Another unusual feature present in this case was the sudden onset of symptoms, amaurosis fugax in the left eye and ipsilateral esotropia due to involvement of the optic nerve and lateral rectus muscle, respectively.

RCC treatment depends on the evolution stage of the disease, and it presents options for clinical and surgical treatments. Molecular-targeted therapies are currently the clinical treatment of choice. They are more effective against RCC than chemotherapy, with response rates of approximately 40 and $10 \%$, respectively. There are several ongoing studies investigating new drugs for the systemic treatment of $\mathrm{RCC}^{3}$.

Until recently, complete RCC resection was gold standard therapy in cases with strictly localized disease.
Surgery occurred adequately, without complications, and the patient was discharged after 4 days. Histopathology of the tissue removed during nephrectomy revealed renal parenchyma, hosting a neoplasia of epithelial origin composed of atypical cells, irregular nuclei and macronuclei, with abundant clear cytoplasm in tubular and cordonal arrangements suggestive of CCRC (Figure 4).

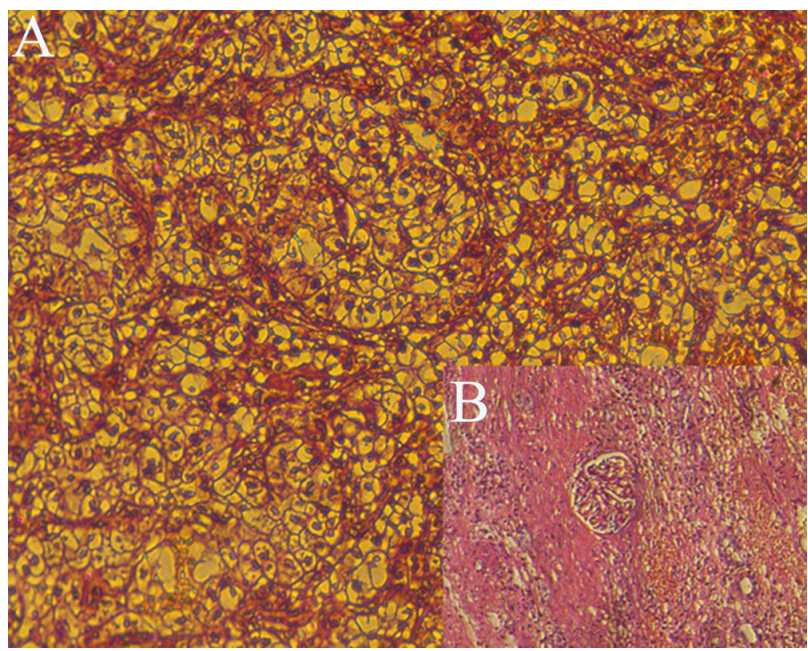

Figure 4. A: Histopathology of the tissue removed during partial nephrectomy of the left kidney Renal parenchyma hosting neoplasia of epithelial origin composed of atypical cells, irregular nuclei and macronuclei, with abundant clear cytoplasm in tubular and cordonal arrangements suggestive of Clear Cell Renal Carcinoma. B: Some healthy glomerular regions interspersed with others affected by neoplasia can be seen. H\&E staining x20

However, it is now known that in smaller tumors it is possible to proceed with less aggressive approaches. In tumors of up to 4 centimeters, partial nephrectomy is chosen because there is no significant difference in survival, and long-term recurrent disease in detriment of radical nephrectomy ${ }^{4}$.

Surgical treatment also plays an important role in patients who already have distant metastasis. One study compared isolated immunotherapy versus nephrectomy plus immunotherapy in patients with metastatic RCC. The results showed greater long-term survival in the group of patients submitted to therapy combined with surgical approach $^{4}$.

\section{CONCLUSION}

In this case report, even though the patient presented metastasis to lung and orbit after partial nephrectomy, he evolved with good postoperative recovery in a one-month segment; and the patient was referred to a reference center for oncology for post-surgical follow-up.

Acknowledgments: No funding was used in the production of this article.

Author disclosure statement: None of the contributing authors have any conflict of interest, including specific financial interests or 
Cavalcante-Filho JRM, et al. Orbital metastasis of clear cell renal carcinoma.

relationships and affiliations relevant to the subject matter or materials discussed in the article. No competing financial interests exist.

Participação dos autores na elaboração do Relato de Caso: José Renan Miranda Cavalcante Filho e Karlos Jennysson Sousa Soares - Coleta de dados; José Renan Miranda Cavalcante Filho, Rafael Paiva Arruda, Elson Arruda Linhares, Paulo Roberto Lacerda Leal, Irismar de Azevedo Andrade e Karlos Jennysson Sousa Soares - Revisão de literatura; José Renan Miranda Cavalcante Filho, Rafael Paiva Arruda, Paulo Roberto Lacerda Leal e Karlos Jennysson Sousa Soares - Escrita do artigo.

\section{REFERENCES}

1. Lopez-Beltran A, Scarpelli M, Montironi R, Kirkali Z. 2004 WHO classification of renal tumours of the adults. Eur Urol. 2006;49:798- 805. doi: 10.1016/j.eururo.2005.11.035

2. Shields JA, Shields CL, Scartozzi R. Survey of 1264 patients with orbital tumors and simulating lesions. The Montgomery Lecture, Part I. Opthalmology. 2004;111:997-1008.4. doi: 10.1016/j.ophtha.2003.01.002

3. Motzer RJ, Hutson TE, Tomczak P, Michaelson MD, Bukowski RM, Oudard S, et al. Overall survival and updated results for sunitinib compared with interferon alfa in patients with metastatic renal cell carcinoma. J Clin Oncol. 2009;27:3584. doi: 10.1200/JCO.2008.20.1293

4. Ljungberg B, Cowan NC, Hanbury DC, Hora M, Kuczyk MA, Merseburger AS, Patard JJ, Mulders PF, Sinescu IC; European Association of Urology Guideline Group. EAU guidelines on renal cell carcinoma: the 2010 update. Eur Urol. 2010;58(3):398-406. doi: 10.1016/j.eururo.2010.06.032.

Recebido: 04.06.17

Aceito: 05.08.19 